\title{
ANALISIS DAMPAK KABUT ASAP KARHUTLA TERHADAP GANGGUAN KESEHATAN FISIK
}

\author{
Putra Mulia $^{1}$, Nofrizal ${ }^{2}$, Wan Nishfa Dewi ${ }^{3}$ \\ 1Mahasiswa Pascasarjana Program Studi Ilmu Lingkungan, Universitas Riau \\ 2 Dosen Pascasarjana Ilmu Lingkungan Universitas Riau \\ 3Dosen KJFD KMB, Fakultas Keperawatan Universitas Riau \\ PSIL Universitas Riau Jalan Pattimura No 9 Pekanbaru Riau \\ Kode Pos 28131 Indonesia email: putramul@gmail.com \\ email: aan_fish@yahoo.com
}

\begin{abstract}
Abstrak
Kebakaran hutan dan lahan di Indonesia pada tahun 2019 telah menyebabkan bencana kabut asap dan kota Pekanbaru menjadi salah satu wilayah yang terdampak. Penelitian ini bertujuan untuk menganalisis dampak kesehatan fisik akibat bencana kabut asap. Data yang dikumpulkan adalah data harian ISPU dan kunjungan pasien ke Puskesmas dengan keluhan ISPA, asma, iritasi mata, iritasi kulit dan diare akibat kabut asap, selama periode Karhutla tahun 2019. Metode analisis gangguan kesehatan fisik menggunakan korelasi Spearman's rho. Hasil penelitian menunjukkan ISPU tertinggi yaitu 374 (sangat tidak sehat). Hasil penelitian menunjukkan kadar ISPU terhadap penyakit asma $(p=0,000)$, ISPA $(p=0,000)$, pneumonia $(p=0,005)$, iritasi mata $(p=0,000)$, iritasi kulit $(p=0,001)$ dan diare $(p$ $=0,002$ ), sehingga dapat disimpulkan bahwa kadar ISPU berhubungan signifikan dengan gangguan kesehatan fisik. Disarankan kepada peneliti selanjutnya, perlu melakukan studi cohort lanjutan terkait dampak kebakaran hutan dan lahan terhadap gangguan kesehatan fisik.
\end{abstract}

Kata kunci: Bencana, kabut asap, ISPU, gangguan kesehatan

\begin{abstract}
Forest and land fires in Indonesia on 2019, has caused haze disaster. Pekanbaru is one of the affected cities. The purpose of the study was to analyze the effect of pollutant exposure towards physical health problems. The data was collected using daily Air Quality Index (AQI) and patient visited to Public Health Center with complaints of acute respiratory infection, asthma, conjungtivitis, dermatitis and diarrhea, during the 2019 haze disaster period. The analysis of physical health effect due to pollutant exposure used Spearman's rho correlation. Results of this study depict that the concentration of particulate matter with diameters less than or equal to 10 micrometer reached 374 point (very unhealthy) with variety of correlation results. Spearman's rho correlation result obtained between AQI and asthma $(p=0.000)$, acute respiratory infections $(p=0.000)$, pneumonia $(p=0,005)$, conjunctivitis $(p=0.000)$, dermatitis $(p=0.001)$, and diarrhea $(p=0.002)$. It can be concluded that there is a significant relationship betwwen unhealthy air quality with physical health problems. Based on the findings of this study, it can be suggested for further study to conduct cohort studies that is related to the impact of forest and land fires on physical health problems.
\end{abstract}

Keywords: Disaster, haze, AQI, health problem

\section{PENDAHULUAN}

Kebakaran hutan dan lahan di Indonesia menunjukkan fenomena yang mengkhawatirkan, karena telah hilangnya kawasan hutan sebesar 857,756 hektare (ha) selama periode Januari - September 2019. Salah satu daerah yang paling terdampak yaitu Provinsi Riau dengan angka karhutla mencapai 75,871 ha. Kebakaran hutan dan lahan dapat menjangkau wilayah lain 
Putra Mulia, Nofrizal, Wan Nishfa Dewi, Analisis Dampak Kabut Asap Karhutla terhadap Gangguan Kesehatan Fisik

diluar areal kebakaran, karena menghasilkan kabut asap tebal yang jangkauannya luas. Sebaran kabut asap dapat mencapai wilayah perkotaan dan pemukiman warga yang menyebabkan perubahan kualitas udara sehingga terjadi pencemaran udara. Materi partikulat atau Particulate Matter (PM) adalah indikator utama pada asap kebakaran dengan rentang dalam rentang jam atau mingguan (Faisal, et al., 2012). Akumulasi peningkatan kadar PM menyebabkan perubahan kualitas udara sehingga terjadi pencemaran udara.

Pencemaran udara diukur dengan mengacu pada Keputusan Menteri Lingkungan Hidup Nomor 10 Tahun 1997 tentang Indeks Standar Pencemar Udara (ISPU). Rentang ISPU terbagi menjadi kategori baik, sedang, tidak sehat, sangat tidak sehat dan berbahaya (KemenLH, 1997). DLHK Kota Pekanbaru (2019) mencatat pada tanggal 14 September 2019, nilai ISPU di Kota Pekanbaru adalah 114 yang berarti kualitas udara Pekanbaru pada periode tersebut pada kategori tidak sehat. Kualitas udara yang tidak sehat berpotensi menimbulkan gangguan kesehatan manusia.

Masalah kesehatan yang timbul akibat asap tersebut terutama terjadi pada individu yang berisiko, diantaranya pasien dengan gangguan jantung dan pernafasan, kelompok usia lanjut, ibu hamil dan menyusui serta balita (Susanto, 2019). Menurut Awaluddin
(2016), kualitas udara akibat kabut asap menyebabkan timbul penyakit iritasi mata, batuk, flu, sakit kepala, sesak nafas dan alergi di kulit. Penelitian lain mengungkapkan bahwa ada hubungan yang signifikan antara nilai ISPU dengan keluhan gangguan pernafasan (Hermawan, et al., 2006). Bencana asap yang terjadi pada Tahun 2015 telah berdampak kepada 100,300 angka kesakitan di Indonesia, Malaysia dan Singapura (Koplitz, 2016).

Menurut Dinas Kesehatan Provinsi Riau (2019), jumlah penderita ISPA meningkat jika dibandingkan bulan Juli sebanyak 27,563 orang dan bulan Agustus menjadi 29,346 orang. Dibandingkan dengan Kabupaten/Kota lain di Provinsi Riau, penderita ISPA paling banyak berada di Kota Pekanbaru yakni 7.377 orang. Menurut Dinas Kesehatan Kota Pekanbaru (2019) jumlah penderita ISPA di Kota Pekanbaru pada periode bulan Agustus 2019 meningkat jika dibandingkan pada bulan Mei (3,574 kasus) Juni (3,523 kasus). Dengan demikian, bencana kabut asap yang terjadi pada Tahun 2019, berdampak negatif terhadap kesehatan masyarakat.

Berdasarkan uraian latar belakang tersebut maka tujuan penelitian ini yaitu untuk menganalisis kualitas ISPU Kota Pekanbaru dan menganalisis dampak kabut asap karhutla terhadap gangguan kesehatan 
fisik, selama bencana karhutla Tahun 2019 di Kota Pekanbaru.

\section{METODE PENELITIAN}

Penelitian ini dilakukan di Kota Pekanbaru, pada bulan Mei - Juli 2020. Pengambilan data parameter kualitas ISPU diambil dari data Laboratorium Udara DLHK Kota Pekanbaru. Data gangguan kesehatan fisik didapat dari angka kunjungan pasien di 21 Puskesmas Kota Pekanbaru dengan keluhan ISPA, diare, pneumonia, asma, iritasi mata dan iritasi kulit akibat kabut asap.

Data ISPU dianalisis secara deskriptif dengan membuat grafik perbandingan jumlah polutan perbulan. Data jenis penyakit gangguan fisik dilakukan analisis korelasi untuk menganalisis hubungan antara ISPU terhadap gangguan kesehatan fisik masyarakat. Analisis korelasi yang digunakan adalah Korelasi Spearman Rho menggunakan Software SPSS Versi 24.

\section{HASIL PENELITIAN}

\section{Kualitas ISPU Kota Pekanbaru}

Hasil penelitian pada tabel 1 . menunjukkan nilai rata-rata ISPU paling rendah tercatat bulan Oktober yaitu 26 (kategori baik) dan tertinggi pada bulan September yaitu 374 (kategori berbahaya).
Tabel 1

Kadar ISPU Juli - Oktober di Pekanbaru

\begin{tabular}{cccc}
\hline \multirow{2}{*}{$\begin{array}{c}\text { Periode } \\
\text { Bulan }\end{array}$} & $\begin{array}{c}\text { Rentang } \\
\text { ISPU Harian }\end{array}$ & $\begin{array}{c}\text { Rata-rata ISPU } \\
\text { (per hari) }\end{array}$ & $\begin{array}{c}\text { Rata-rata } \\
\text { Kategori ISPU } \\
\text { (perhari) }\end{array}$ \\
\hline Juli & $31-61$ & $42,10 \pm 8,001 /$ & Baik \\
Agustus & $31-90$ & $59,84 \pm 13,995$ & Sedang \\
September & $39-374$ & $113,53 \pm$ & Tidak Sehat \\
Oktober & $26-67$ & 41,437 & Baik \\
\hline
\end{tabular}

Tingkat pencemaran udara di bulan September pada tingkat yang sangat tidak sehat dan berbahaya. Dampak yang mungkin timbul adalah gangguan kesehatan pada sejumlah segmen populasi yang terpapar dan secara umum dapat merugikan kesehatan yang serius pada populasi rentan (KemenLH, 1997).

\section{Dampak Kabut Asap Karhutla terhadap Gangguan Kesehatan}

\section{Fisik}

Kabut asap akibat karhutla dapat mengganggu kesehatan manusia, baik yang dalam kondisi sehat maupun sakit. Gangguan kesehatan dirasakan oleh manusia jika terpapar dengan asap, antara lain: memperburuk asma dan penyakit paru kronis lain, seperti bronkitis kronis, menyebabkan infeksi saluran pernapasan akut (ISPA), iritasi lokal pada selaput lendir di hidung, mulut dan tenggorokan, iritasi pada mata dan kulit, menimbulkan keluhan gatal, mata berair, peradangan dan infeksi yang memberat. Gangguan lain yang timbul termasuk pada sistem saluran cerna, jika mengkonsumsi 
Putra Mulia, Nofrizal, Wan Nishfa Dewi, Analisis Dampak Kabut Asap Karhutla terhadap Gangguan Kesehatan Fisik

makanan dan air yang terkontaminasi polutan asap, memperburuk berbagai penyakit kronik di berbagai organ tubuh serta menurunkan daya tahan tubuh atau menimbulkan stres (Kemenkes, 2016).

Berikut ini, penulis menampilkan analisis deskriptif dampak kabut asap terhadap gangguan kesehatan fisik berdasarkan kelompok jenis kelamin, umur, perbandingan kualitas udara dan gangguan kesehatan fisik, serta analisis korelasi kadar ISPU terhadap gangguan kesehatan fisik.

\subsection{Distribusi responden menurut} kelompok jenis kelamin dan umur

Analisis deskriptif digunakan untuk menggambarkan distribusi gangguan kesehatan fisik akibat polutan asap karhutla. Pada bagian ini, ditampilkan gambaran predisposisi gangguan kesehatan fisik akibat kabut asap karhutla berdasarkan jenis kelamin dan berbagai kelompok kelompok umur.

\section{Tabel 2}

Distribusi responden menurut kelompok jenis kelamin

\begin{tabular}{ccccccc}
\hline \multirow{2}{*}{ Penyakit } & \multicolumn{2}{c}{ Laki-laki } & \multicolumn{2}{c}{ Perempuan } & \multicolumn{2}{c}{ Total } \\
\cline { 2 - 7 } & $\mathrm{Jlh}$ & $\%$ & $\mathrm{Jlh}$ & $\%$ & $\mathrm{Jlh}$ & $\%$ \\
Asma & 263 & 47,6 & 290 & 52,4 & 553 & 100 \\
ISPA & 5835 & 47,8 & 6378 & 52,2 & 12213 & 100 \\
Pneumoni & 101 & 59,4 & 148 & 40,6 & 249 & 100 \\
Iritasi Mata & 124 & 52,5 & 112 & 47,5 & 236 & 100 \\
Iritasi Kulit & 388 & 52,9 & 345 & 47,1 & 733 & 100 \\
Diare & 495 & 55,1 & 403 & 44,9 & 898 & 100 \\
\hline
\end{tabular}

Berdasarkan tabel 2. menunjukkan, berdasarkan jenis kelamin, pasien asma dan ISPA lebih banyak diderita oleh perempuan dibandingkan laki-laki. Sementara, pasien yang mengalami pneumoni, iritasi mata, iritasi telinga dan diare pada laki-laki lebih banyak dibandingkan perempuan.

\section{Tabel 3}

Distribusi responden menurut kelompok

\begin{tabular}{cccccc}
\multicolumn{1}{l|}{$\begin{array}{c}\text { umur } \\
\text { Umur }\end{array}$} & $\begin{array}{c}0-1-4 \\
\text { Tahun } \\
\%\end{array}$ & $\begin{array}{c}\text { Tahun } \\
\%\end{array}$ & $\begin{array}{c}5-15 \\
\text { Tahun } \\
\%\end{array}$ & $\begin{array}{c}>15 \\
\text { Tahun } \\
\%\end{array}$ & $\begin{array}{c}\text { Total } \\
\%\end{array}$ \\
Asma & 2,4 & 8,5 & 17,5 & 71,6 & 100 \\
ISPA & 5,1 & 18,1 & 26,4 & 50,4 & 100 \\
Pneumoni & 25,7 & 53 & 13,7 & 7,6 & 100 \\
Iritasi Mata & 3,3 & 15,7 & 22,5 & 58,5 & 100 \\
Iritasi Kulit & 3,1 & 15,1 & 20,5 & 61,3 & 100 \\
Diare & 6,8 & 24,3 & 26,2 & 42,7 & 100 \\
\hline
\end{tabular}

Berdasarkan tabel 3 menunjukkan, pasien asma, ISPA, iritasi mata, iritasi telinga dan diare lebih banyak terjadi pada kelompok umur >15 tahun. Sementara, pasien yang mengalami pneumoni, mayoritas pada kelompok umur $0-1$ tahun.

1.2. Perbandingan kualitas udara dan gangguan kesehatan fisik akibat kabut asap karhutla

Analisis deskriptif digunakan untuk membandingkan kualitas udara dengan rata-rata frekuensi masyarakat yang mengalami gangguan kesehatan akibat 
kabut asap, yaitu asma, ISPA, pneumonia, iritasi mata, iritasi kulit dan diare.

\section{Tabel 4}

Perbandingan kualitas udara dan gangguan kesehatan fisik akibat kabut asap karhutla

\begin{tabular}{|c|c|c|c|c|c|}
\hline $\begin{array}{r}\text { Kualita } \\
\text { Udara }\end{array}$ & Baik & Sedang & $\begin{array}{l}\text { Tidak } \\
\text { Sehat }\end{array}$ & $\begin{array}{l}\text { Sangat Tidakk } \\
\text { Sehat dan } \\
\text { Berbahaya } \\
\end{array}$ & $\begin{array}{l}\text { kualitas udara diikuti dengan peningkatan } \\
\text { rata-rata kejadian penyakit iritasi mata. }\end{array}$ \\
\hline Asma & $\begin{array}{c}4,5 \\
\text { orang }\end{array}$ & $\begin{array}{c}8,1 \\
\text { orang }\end{array}$ & $\begin{array}{c}13,7 \\
\text { orang }\end{array}$ & 15 orang & Hal ini dapat dilihat pada saat kualitas \\
\hline ISPA & $\begin{array}{c}88,7 \\
\text { orang }\end{array}$ & $\begin{array}{l}188,8 \\
\text { orang }\end{array}$ & $\begin{array}{l}353,7 \\
\text { orang }\end{array}$ & 539 orang & udara sangat tidak sehat dan berbahaya \\
\hline Pneumoni & $\begin{array}{c}2,5 \\
\text { orang }\end{array}$ & $\begin{array}{c}3,7 \\
\text { orang }\end{array}$ & $\begin{array}{c}4,6 \\
\text { orang }\end{array}$ & 12 orang & rata-rata kasus iritasi mata adalah 10 \\
\hline Iritasi Mata & $\begin{array}{c}2,4 \\
\text { orang }\end{array}$ & $\begin{array}{c}3,4 \\
\text { orang }\end{array}$ & $\begin{array}{c}7,7 \\
\text { orang }\end{array}$ & 10 orang & orang, meningkat dibandingkan ketika \\
\hline Iritasi Kulit & $\begin{array}{c}4,6 \\
\text { orang }\end{array}$ & $\begin{array}{c}11,2 \\
\text { orang }\end{array}$ & $\begin{array}{l}11,7 \\
\text { orang }\end{array}$ & 14,5 orang & kualitas udara baik (2,46 orang) dan \\
\hline Diare & $\begin{array}{c}5,9 \\
\text { orang }\end{array}$ & $\begin{array}{c}13,1 \\
\text { orang }\end{array}$ & $\begin{array}{c}11,4 \\
\text { orang }\end{array}$ & 10 orang & sedang ( 3,45 orang). Penurunan kualitas \\
\hline
\end{tabular}

Berdasarkan output pada tabel 4 menunjukkan, penurunan kualitas udara diikuti peningkatan kejadian asma. Hal ini dilihat pada saat kualitas udara sangat tidak sehat dan berbahaya rata-rata kasus asma sebanyak 15 orang, meningkat dibandingkan ketika kualitas udara baik $(4,54)$ dan sedang $(8,13)$. Penurunan kualitas udara juga diikuti dengan peningkatan rata-rata kejadian ISPA. Hal ini dapat dilihat pada saat kualitas udara sangat tidak sehat dan berbahaya rata-rata kasus ISPA adalah 539, meningkat dibandingkan ketika kualitas udara baik $(88,73)$ dan sedang $(188,83)$. Perbandingan kualitas udara dengan penyakit pneumoni menunjukkan adanya penambahan kasus pneumoni saat kualitas udara sangat tidak sehat dan berbahaya. Hal ini dapat dilihat pada saat kualitas udara sangat tidak sehat dan berbahaya rata-rata kasus pneumonia adalah 12 orang, meningkat dibandingkan ketika kualitas udara baik $(2,54)$ dan sedang $(3,75)$.

Berdasarkan tabel 4, penurunan udara juga diikuti dengan peningkatan rata-rata kejadian iritasi kulit. Hal ini dapat dilihat pada saat kualitas udara sangat tidak sehat dan berbahaya rata-rata kasus iritasi kulit adalah 14,50 meningkat dibandingkan ketika kualitas udara baik $(4,62)$ dan sedang $(11,25)$. Perbandingan kualitas udara dengan penyakit diare diikuti dengan peningkatan rata-rata kejadian penyakit diare. Hal ini dapat dilihat pada saat kualitas udara tidak sehat $(11,45)$ dengan kualitas udara sangat tidak sehat dan berbahaya (10) kasus diare meningkat dibandingkan saat kualitas udara baik $(5,92)$. 
Putra Mulia, Nofrizal, Wan Nishfa Dewi, Analisis Dampak Kabut Asap Karhutla terhadap Gangguan Kesehatan Fisik

\subsection{Analisis korelasi kadar ISPU dengan gangguan kesehatan fisik}

Hasil analisis korelasi spearman rho kadar ISPU terhadap gangguan kesehatan fisik tersaji pada berikut:

\section{Tabel 5}

Uji Korelasi Spearman ISPU dan gangguan fisik

\begin{tabular}{lccc}
\hline \multicolumn{3}{c}{ Correlations } \\
\hline \multirow{3}{*}{ Penyakit } & $\mathrm{N}$ & $\begin{array}{c}\text { Spearman's } \\
\text { rho }\end{array}$ & $\begin{array}{r}\text { Sig. (2- } \\
\text { tailed) }\end{array}$ \\
\cline { 2 - 4 } & & $0,615^{* *}$ & 0,000 \\
\hline Asma & 79 & $0,736^{* *}$ & 0,000 \\
ISPA & 79 & $0,311^{* *}$ & 0,005 \\
Pneumonia & 79 & $0,523^{* *}$ & 0,000 \\
Iritasi Mata & 79 & $0,364^{* *}$ & 0,001 \\
Iritasi Kulit & 79 & $0,344^{* *}$ & 0,002 \\
Diare & 79 & & \\
**. Correlation is significant at the 0.01 level $(2-$ & \\
tailed). & \multicolumn{3}{c}{}
\end{tabular}

Berdasarkan output pada tabel 5 menunjukkan, kadar ISPU berhubungan signifikan terhadap penyakit asma (Sig. 0,000), ISPA (Sig. 0,000), pneumonia (Sig. 0,005), iritasi mata (Sig. 0,000), iritasi kulit (Sig. 0,001) dan diare (Sig. 0,002).

Tingkat kekuatan hubungan antara kadar ISPU dengan asma (coef. correlattion 0,615 ) dan ISPA (coef. correlattion 0,736 ) adalah kuat. Tingkat kekuatan hubungan antara kadar ISPU dengan iritasi mata (coef. correlattion 0,523) adalah cukup kuat. Kekuatan hubungan antara kadar ISPU dengan pneumonia (coef. correlattion
0,3611), iritasi kulit (coef. correlattion 0,364) dan diare (coef. correlattion 0,344) adalah lemah.

Angka correlation coefficient bernilai positif. Dengan demikian, hubungan antara variabel kadar ISPU dan gangguan kesehatan fisik bersifat searah.

\section{PEMBAHASAN}

\section{Kualitas ISPU Kota Pekanbaru}

Peningkatan kadar ISPU pada rentang bulan Juli - Oktober 2019 disebabkan karena kebakaran hutan dan lahan di beberapa wilayah di Provinsi Riau dan sekitarnya. Tercatat selama periode Juli - Oktober 2019 luas kebakaran hutan dan lahan di Provinsi Riau berjumlah 6,445 ha, meningkat dibandingkan Januari - Juni sebanyak 3,272 ha (BPBD Provinsi Riau, 2019).

Pada periode bulan Maret hingga Mei yang berarti peralihan antara musim penghujan dan musim kemarau, jumlah hotspot tercatat lebih sedikit, jika dibandingkan dengan musim kemarau yang terjadi pada periode bulan Juni hingga Agustus. Dari bulan Juli hingga September, jumlah hotspot meningkat drastis, yang berkaitan dengan berkurangnya curah hujan dan meningkatnya temperatur udara. Jumlah hotspot paling banyak terjadi pada bulan September meningkat tajam 
dibandingkan bulan Juli (Aflahah et al., 2018).

Menurut Syaufina dan Sukmana (2008), penurunan jumlah curah hujan berkaitan erat dengan penurunan jumlah hotspot pada bulan-bulan tertentu. Pada bulan Oktober hingga Desember, curah hujan meningkat yang menyebabkan jumlah hotspot berkurang drastis. Sebaliknya, pada periode bulan Mei hingga September dengan tingkat kelembaban lebih tinggi dan curah hujan rendah, terdapat titik hotspot dengan jumlah yang tinggi. Peningkatan jumlah hotspot merupakan indikasi intensitas kebakaran hutan dan lahan yang juga akan meningkat. Jika potensi kebakaran semakin meningkat, maka berdampak dengan meningkatnya jumlah kabut asap yang naik ke atmosfer.

\section{Dampak Kabut Asap Karhutla} terhadap Gangguan Kesehatan Fisik

2.1. Gambaran karakteristik responden menurut kelompok jenis kelamin dan umur

Menurut kelompok jenis kelamin, mayoritas pasien asma dan ISPA berjenis kelamin perempuan. Hal ini didukung oleh penelitian Kunii et al. (2002) yang menyebutkan bahwa perempuan lebih rentan terkena gangguan pernafasan dibandingkan laki-laki. Menurut Susanto et al. (2019), populasi sensitif dapat mengalami gejala yang lebih berat, diantaranya ibu hamil dan pasien dengan riwayat asma. Faisal, et al. (2012), menjelaskan bahwa gas $\mathrm{CO}$ dan hidrokarbon aromatik polisiklik (HAP) dapat menyebabkan kejadian eksaserbasi asma atau hipereaktivitas bronkus, karena dapat mengiritasi mukosa saluran pernafasan yang ditunjukkan dengan kerusakan membran sel dan sel epitel.

Secara umum laki-laki lebih banyak mengalami iritasi mata dan iritasi kulit dibandingkan perempuan. Hal ini berkaitan dengan aktivitas laki-laki yang lebih sering diluar rumah sehingga risiko terpapar polutan kabut asap lebih tinggi. Hasil penelitian ini sejalan dengan Awaluddin (2016) yang menyatakan bahwa sebanyak $4,7 \%$ masyarakat mengalami keluhan mata perih akibat kabut asap. Pengaruh langsung dari polusi udara terhadap kesehatan manusia tergantung pada intensitas dan lamanya pemaparan, status kesehatan penduduk yang terpapar dan karakteristik individu seperti usia, komorbid, infeksi lain, serta jenis dan ukuran partikel.

Berdasarkan hasil penelitian diketahui bahwa mayoritas pasien dengan gangguan asma, ISPA, iritasi mata, iritasi kulit dan diare adalah kelompok umur $>15$ tahun. Hasil penelitian ini sejalan dengan Awaluddin (2016) yang menyatakan bahwa kelompok usia 18 - 
Putra Mulia, Nofrizal, Wan Nishfa Dewi, Analisis Dampak Kabut Asap Karhutla terhadap Gangguan Kesehatan Fisik

60 tahun merupakan kelompok usia yang terbanyak mengalami keluhan kesehatan akibat kabut asap sebesar 40,8\%. Hal ini berkaitan dengan tingginya aktifitas diluar rumah pada kelompok usia produktif sehingga lebih berisiko terpapar polutan kabut asap. Selain itu, menurut Faisal, et al. (2012) fungsi penyaringan partikel udara pada mekanisme pertahanan saluran napas individu dewasa yang berusia lebih dari 35 tahun, mengalami penurunan akibat penurunan fungsi fisiologis tubuh. Resiko infeksi saluran napas oleh mikroorganisme akibat penekanan aktivitas makrofag meningkat seiring tingginya intensitas terpapar polutan.

Mayoritas pasien pneumonia berada pada kelompok umur 1-4 tahun. Menurut Kemenkes (2018) di Indonesia, period prevalence pneumonia tertinggi terjadi pada kelompok umur $1-4$ tahun. Angka kematian akibat pneumonia pada balita sebesar 1,19\%. Pada kelompok bayi, angka kematian lebih tinggi, yaitu sebesar 2,89\% dibandingkan kelompok umur 1 - 4 tahun (0,20\%). Menurut Pudiastuti (2011), lingkungan yang berpolusi, perubahan cuaca, riwayat terpaapr asap dan debu merupakan faktor pencetus terjadinya pneumonia pada balita.
2.2. Perbandingan kualitas udara dan gangguan kesehatan fisik akibat kabut asap karhutla

Berdasarkan arah fluktuasi antara kualitas udara dengan penyakit asma terlihat bahwa pertambahan kasus asma mengikuti tren penurunan kualitas udara. Hal ini sejalan dengan Susanto et al., (2019) setiap kenaikan PM10 dari 50 ug/m3 menjadi $150 \mathrm{ug} / \mathrm{m} 3$ menyebabkan peningkatan kasus asma sebesar 19\%. Tahapan terjadinya asma sejak mulai terpapar kabut asap mengikuti riwayat alamiah penyakit asma tersebut. Mulai dari tahap prepatogenesis, tahap inkubasi/patogenesis, tahap penyakit dini, tahap penyakit lanjut hingga tahap penyakit akhir. Tahapan-tahapan ini dapat berlangsung beberapa menit hingga beberapa jam. Menurut Yudhawati dan Krisdanti (2017) pada penyakit asma terjadi inflamasi yang disebabkan hiperresponsif otot polos pada saluran napas dalam waktu 15 - 30 menit dan dapat menghilang dalam $2-3$ jam. Respon asma yang ditandai dengan bronko konstriksi terjadi setelah 3 - 4 jam terinhalasi alergen dan dapat berlangsung hingga 24 jam.

Saat kualitas udara pada status sangat tidak sehat dan terlihat bahwa terjadi peningkatan kasus ISPA yang signifikan. Hasil penelitian ini sejalan dengan 
Hermawan, et al. (2016), perubahan kadar ISPU hampir serupa dengan kasus ISPA. Asap yang dihasilkan dari kebakaran hutan dan lahan mengandung komponenkomponen dalam bentuk partikel maupun gas yang bersifat iritan bagi saluran napas. Saluran napas yang terpapar akan mengalami proses inflamasi dengan gejala pilek, nyeri tenggorokan, batuk-batuk dan diikuti dengan peningkatan suhu tubuh. Proses terjadinya penyakit ISPA dimulai dari masa inkubasi yang dapat berlangsung 1 - 4 hari sejak polutan masuk kedalam saluran pernapasan. Manifestasi klinis ISPA yang ditandai dengan gejala pilek, nyeri tenggorokan, batuk-batuk dan peningkatan suhu badan berlangsung selama $4-7$ hari (Smeltzer, 2016).

Kualitas udara yang sangat tidak sehat dan berbahaya juga mengakibatkan terjadinya peningkatan kasus pneumoni. Hal ini disebabkan $\mathrm{PM}_{10}$ dapat terinhalasi ke dalam paru-paru dan saluran napas yang menyebabkan iritasi. Keadaan ini diperparah akibat reaksi sinergis dengan gas SO2 di udara. Fase penyakit pneumoni sejak terpapar polutan asap, mengikuti riwayat alamiah penyakit mulai dari fase subklinis hingga fase klinis dapat berlangsung selama $9-21$ hari, dengan rata-rata masa inkubasi 12 hari (Smeltzer, 2016).
Asap karhutla, dalam jangka pendek menyebabkan iritasi selaput lendir mata. Iritasi mata merupakan penyakit akut yang disebabkan kontaminasi langsung polutan pada selaput jaringan mata, sehingga menimbulkan gejala mata perih dan berair. Peningkatan kasus iritasi mata pada saat kualitas udara sangat tidak sehat, disebabkan asap yang dihasilkan dari hutan dan lahan yang terbakar mengandung komponen-komponen dalam bentuk partikel maupun gas. Sebagian besar gas dan partikel asap karhutla tersebut bersifat iritan menyebabkan iritasi membran mukosa mata.

Penambahan kasus iritasi kulit mengikuti tren penurunan kualitas udara. Faisal, et al. (2012) menyebutkan bahwa kandungan dalam asap dan debu diantaranya adalah SPM dan Pb. Mekanisme kontaminasi dapat melalui pajanan langsung melalui kulit. Konsentrasi yang tinggi dari partikelpartikel tersebut merupakan zat irritant pada kulit sehingga menimbulkan gejala gatal-gatal dan kemerahan pada kulit yang sensitif. Riwayat alamiah penyakit iritasi kulit akibat polutan udara hingga menunjukkan gejala membutuhkan waktu tertentu mulai dari jam hinga beberapa hari. Menurut Dijkhoff et al., (2020), kontaminasi $\mathrm{PM}_{2,5}$ yang berlangsung 
Putra Mulia, Nofrizal, Wan Nishfa Dewi, Analisis Dampak Kabut Asap Karhutla terhadap Gangguan Kesehatan Fisik

selama $2-4$ hari menyebabkan penurunan jumlah dan silia di kulit, mengurangi produksi keratin dan meningkatkan reaksi inflamasi.

Penurunan kualitas udarajuga diikuti dengan peningkatan kasus diare, yaitu pada kondisi ISPU meningkat pada bulan Juli September 2019, kasus diare tercatat tinggi dan pada saat ISPU menurun jumlah kasus diare ikut turun. Meskipun demikian, puncak kasus diare tidak bertepatan terjadi pada saat kadar puncak ISPU. Jumlah penderita diare terbanyak (31 orang) pada 8 Agustus 2019, sedangkan ISPU paling tinggi terjadi pada 23 September 2019 (374). Hal ini dikarenakan riwayat alamiah penyakit diare mulai dari fase prepatogenesis hingga pospatogenesis dapat berlangsung $2-4$ hari (Smeltzer, 2016).

\subsection{Hubungan kadar ISPU dengan} gangguan kesehatan fisik

Indikator utama asap kebakaran hutan dan lahan adalah Particulate Matter (PM) dengan diameter $<1 \mu \mathrm{m}$ sampai maksimal $500 \mu \mathrm{m}$. Pajanan PM yang terhirup oleh manusia tergantung dari komposisi PM yang bervariasi ukuran partikulatnya. Partikel asap dengan ukuran fraksi setara $\mathrm{PM}_{2,5}$ dapat menyebar dalam cahaya dan mengganggu jarak pandang. Partikel yang halus tersebut dapat terinhalasi hingga ke paru-paru, dan berisiko menimbulkan gangguan kesehatan. Polutan udara lain yang dapat mengiritasi saluran pernafasan yaitu akrolein, formaldehid, dan benzena. Secara umum, peningkatan kadar $\mathrm{PM}_{10}$ $\mu \mathrm{m}$ di udara dihubungkan dengan peningkatan berbagai keluhan pernafasan, peningkatan kunjungan ke instansi gawat darurat, peningkatan rawat inap, risiko kematian dan eksaserbasi akut asma bronkial dan penyakit paru obstruktif kronik (WHO, 1999).

Asap dari kebakaran hutan berupa PM merupakan salah satu emisi pembakaran biomassa yang dapat mempengaruhi kesehatan manusia. Particulate Matter yang terinhalasi oleh penderita asma menjadi stimulus eksogen yang menyebabkan jejas sel dan juga menimbulkan reaksi kompleks pada jaringan ikat sehingga menimbulkan inflamasi. Inflamasi melaksanakan tugas pertahanannya dengan mengencerkan, menghancurkan dan menetralkan partikel toksik tersebut (Vinay, et al., 2007). Stimulus awal radang memicu pelepasan mediator kimiawi dari plasma atau dari sel jaringan epitel. Mediator terlarut akan bekerja bersama atau secara berurutan memperkuat respon awal radang dan mempengaruhi perubahannya dengan mengatur respon vaskular dan selular. Gambaran karakteristik patologis yang timbul diantaranya peluruhan sel epitel, hiperplasia kelenjar mukosa, fibrosis dan 
infiltrasi sel inflamasi pada dinding bronkial (Jeffrey \& Theresa, 2014).

Dalam keadaan normal, sel-sel epitel jalan nafas yang terhubung dengan sambungan yang rapat mengeluarkan lendir, cairan lapisan permukaan jalan nafas, peptida pertahanan tubuh, antioksidan dan mengekspresikan reseptor pengenalan pola kekebalan bawaan untuk merespon zat asing dan patogen yang dihirup. Dalam kondisi paparan polusi udara, pertahanan epitel saluran napas terganggu oleh penurunan fungsi penghalang, gangguan pertahanan tubuh terhadap patogen, dan respons inflamasi yang berlebihan. Polisiklik aromatik hidrokarbon (PAH) yang merupakan produk sampingan dari pembakaran bahan bakar fosil dan biomassa dapat menyebabkan stres oksidatif dan merupakan ligan untuk AhR. Selanjutnya AhR memediasi respons transkripsi yang memengaruhi detoksifikasi pada tingkat seluler. Interaksi antara bahan polutan yang dihirup terjadi epitelisasi dengan peningkatan lendir mukosa, surfaktan, silia, dan reseptor permukaan sel yang mempengaruhi fisiologi jalan napas (Huff, et al., 2019). Pada periode akut, asap menyebabkan iritasi bronkus, inflamasi, berkurangnya bersihan mukosilier dan mengurangi respons makrofag dan imunitas lokal. Selain itu terjadi juga reaksi fibrotik akibat jejas pada sel epitel bronkus yang menyebabkan reaktifitas meningkat (Wulan \& Subagio, 2016).

Faisal, et al. (2012) menyebutkan pajanan asap meningkatkan kemungkinan infeksi saluran napas oleh bakteri dan virus akibat penekanan aktivitas makrofag sehingga timbul gejala pneumonia dan komplikasi pernapasan. Penelitian yang dilakukan oleh Anggraini, et al., (2016) menjelaskan bahwa kabut asap yang dihasilkan oleh kebakaran hutan dan lahan dalam bentuk gas dan partikel tidak secara langsung menyebabkan penyakit pneumonia. Ditinjau dari pendekatan ekologi, penyakit pneumonia lebih banyak dipengaruhi oleh cuaca. Pada musim kemarau kandungan NO2 dalam udara mengalami reaksi fotokimia sehingga meningkatkan kadar O3. Pada musim hujan, pneumonia dipengaruhi oleh curah hujan dan kecepatan angin yang menyebabkan udara menjadi lembab.

Penelitian Hermawan dan Lasut (2016) menemukan bahwa jika melihat angka koefisien korelasi antara ISPU di Pekanbaru berhubungan dengan kejadian pneumonia sangat lemah. Meskipun koefisien korelasi antara ISPU dan pneumonia lemah, tetapi hubungan tersebut signifikan. Tingkat korelasi yang lemah tersebut dikarenakan pencemaran 
Putra Mulia, Nofrizal, Wan Nishfa Dewi, Analisis Dampak Kabut Asap Karhutla terhadap Gangguan Kesehatan Fisik

udara bukan merupakan satu-satunya penyebab maupun pencetus utama pneumonia.

Menurut Said (2010), faktor risiko penyakit pneumonia pada anak balita yaitu faktor risiko yang selalu ada (definite risk factors), faktor risiko yang sangat mungkin (likely risk factors) dan faktor risiko yang masih mungkin (possible risk factors). Faktor risiko yang selalu ada adalah malnutrisi, ASI non eksklusif, berat badan lahir rendah (BBLR), imunisasi tidak lengkap, kepadatan rumah dan polusi udara di dalam rumah. Faktor risiko yang sangat mungkin dan masih mungkin yaitu defisiensi vitamin A, pengaruh asap rokok dari orang tua, penyakit jantung, asma, perilaku dan pendidikan ibu, kelembaban, udara dingin, kekurangan zinc, serta diakibatkan polusi udara di luar rumah.

Iritasi mata akibat kabut asap disebabkan oleh particulatte matter yang berukuran lebih dari $10 \mathrm{~mm}$ melalui mekanisme kontak langsung pada selaput lendir mata. Menurut Gunawan, et al. (2012) asap hasil pembakaran lahan gambut di ruang terbuka mengandung beberapa unsur yaitu CO (15 ppm), CO2 (97ppm), methane ( $3 \mathrm{ppm})$, gas oline (74,26 ppm). Asap yang berasal dari kebakaran hutan mengandung campuran gas, partikel dan bahan kimia akibat pembakaran yang tidak sempurna. Komposisi zat tersebut memiliki ukuran $>10 \mu \mathrm{m}$ yang biasanya tidak masuk paru tetapi dapat mengiritasi mata, hidung dan tenggorokan melalui mekanisme kontak langsung pada selaput jaringan. Manifestasi klinis yang muncul ditadai dengan sklera berwarna merah, rasa perih pada mata dan berair. Menurut Susanto et al. (2019) sebanyak 40\% orang yang datang ke pelayanan kesehatan mengeluh sakit kepala dan $50 \%$ mengeluh mata merah dan berair. Gangguan iritasi mata ini bersifat akut (jangka pendek) dan dapat sembuh dengan menggunakan obat tetes mata. Untuk mencegah iritasi pada mata masyarakat diminta untuk mengurangi aktivitas diluar rumah, menjaga kebersihan diri (personal hygiene) dan menggunakan pelindung mata berupa kaca mata atau face shield jika diperlukan (Susanto et al, 2019).

Sebagian besar gas dan partikel dalam asap kebakaran bersifat iritatif, menyebabkan iritasi membran mukosa di kulit. Faisal, et al. (2012) menyebutkan bahwa kandungan dalam asap dan debu diantaranya adalah SPM dan $\mathrm{Pb}$. Konsentrasi yang tinggi dari partikelpartikel tersebut merupakan zat irritant pada kulit sehingga menimbulkan gejala gatal-gatal dan kemerahan pada kulit yang sensitif. Iritasi kulit akibat kabut asap dapat terjadi dikarenakan kulit 
merupakan organ tubuh yang terletak paling luar dan langsung terpapar dengan polutan. Menurut Kim, et al. (2016), PM mempengaruhi perkembangan dan eksaserbasi kulit. PM menginduksi stres oksidatif melalui produksi oksigen reaktif dan sekresi sitokin pro-inflamasi seperti TNF- $\alpha$, IL-1 $\alpha$, dan IL-8. Selain itu, peningkatan produksi ROS seperti superoksida dan radikal hidroksil oleh paparan PM meningkatkan MMP termasuk MMP-1, MMP-2, dan MMP-9, yang mengakibatkan degradasi kolagen. Proses ini menyebabkan peningkatan inflamasi dan penuaan sel kulit.

Particulatte Matter juga terbukti menyebabkan disfungsi barrier kulit dan memicu pembentukan oksigen reaktif melalui mekanisme langsung dan tidak langsung. Hal ini yang menyebabkan stres oksidatif dan aktivasi ruam inflamasi di kulit manusia. Selain itu, terdapat korelasi yang positif antara penuaan ekstrinsik dan risiko relatif eksim atopik dengan peningkatan paparan materi partikulat (Dijkhoff et al, 2020). Penelitian yang dilakukan oleh Araviiskaia, et al (2019) menyebutkan bahwa polutan PM dapat mengaktifkan metabolisme kulit dan jalur inflamasi yang menyebabkan stres oksidatif dengan menurunkan kadar antioksidan. Pencemaran lingkungan akibat PM juga dapat mengurangi kelembapan kulit, meningkatkan laju ekskresi sebum dan kemungkinan memperburuk gejala penyakit kulit inflamasi kronis baik pada anak-anak maupun orang dewasa

Penyakit diare merupakan salah satu penyakit gangguan saluran pencernaan dengan gejala buang air besar dengan konsistensi cair sebanyak 3 kali atau lebih dalam satu hari. Pada pasien korban asap, diare disebabkan pasien mengkonsumsi makanan dan air yang terkontaminasi polutan asap. Hal ini diperparah dengan kurangnya kesadaran untuk menjaga perilaku hidup bersih dan sehat (PHBS) dan kebiasaan mencuci tangan sebelum makan (Kemenkes, 2016). Menurut Prayitno (2019), perilaku masyarakat yang tidak mencuci tangan menggunakan sabun, berkontribusi terhadap terjadinya penyakit diare.

Berdasarkan data Riskesdas (Kemenkes, 2019) kebiasaan mencuci tangan pada penduduk berusia $>10$ tahun di Kota Pekanbaru hanya sebesar 49,54\%, masih rendah dibandingkan dengan target capaian CTPS $70 \%$ dari proporsi penduduk. Selain itu penyakit diare juga dapat disebabkan oleh pemberian MPASI dini pada bayi usia kurang dari 6 bulan (Harahap et al., 2019), status gizi kurang, kualitas jamban dan sumber air bersih yang tercemar (Sugiarto et al., 2019). 
Putra Mulia, Nofrizal, Wan Nishfa Dewi, Analisis Dampak Kabut Asap Karhutla terhadap Gangguan Kesehatan Fisik

Dari hasil analisis data dan pembahasan yang telah dipaparkan oleh peneliti diatas, diketahui bahwa bencana kabut asap akibat kebakaran hutan dan lahan pada Tahun 2019 berdampak buruk bagi kesehatan masyarakat Pekanbaru. Oleh karena itu, setiap individu dan masyarakat perlu melakukan berbagai upaya perlindungan diri untuk meminimalkan masalah kesehatan yang dapat terjadi. Kesadaran bagi setiap individu dan masyarakat mengenai bahaya kesehatan akibat kabut asap perlu ditumbuhkan agar masyarakat dapat secara mandiri terdorong menjaga diri dan lingkungan.

Upaya perlindungan diri tersebut dapat dilakukan melalui kegiatan edukasi terkait bencana kabut asap. Menurut Maharani et al., (2020) pengetahuan masyarakat mengenai upaya perlindungan diri dari bencana kabut asap sudah cukup baik dan konkret, namun masih perlu ditingkatkan. Pemberian edukasi yang tepat pada masyarakat perlu dilakukan untuk menambah wawasan dan meningkatkan kesadaran untuk melindungi diri sehingga dapat mengurangi risiko terjadinya gangguan kesehatan akibat bencana kabut asap. Edukasi yang dapat diberikan antara lain, informasi mengenai standar kualitas udara, gangguan kesehatan dan gejala yang timbul akibat kabut asap, cara penggunaan masker yang tepat dan upaya-upaya perlindungan diri lainnya yang dapat dilakukan, baik di dalam maupun di luar rumah.

Upaya pencegahan dan penanganan dampak kesehatan asap kebakaran hutan harus dilakukan oleh seluruh komponen masyarakat. Masing-masing individu harus melakukan berbagai upaya untuk mencegah terjadinya masalah kesehatan. Kelompok masyarakat, instansi pelayanan kesehatan dan pemerintah juga harus melakukan upaya pencegahan dan penanganan tersebut.

\section{SIMPULAN}

Berdasarkan data hasil penelitian, maka dapat ditarik kesimpulan yaitu sebagai berikut :

1. Nilai rata-rata ISPU di Kota Pekanbaru periode Juli - Oktober 2019 paling rendah paling rendah tercatat bulan Oktober yaitu 26 (kategori baik) dan tertinggi pada bulan September yaitu 374 (kategori berbahaya).

2. Kadar ISPU berhubungan signifikan terhadap penyakit asma (Sig. 0,000), ISPA (Sig. 0,000), pneumonia (Sig. 0,005), iritasi mata (Sig. 0,000), iritasi kulit (Sig. 0,001) dan diare (Sig. 0,002). Tingkat kekuatan hubungan antara kadar ISPU dengan asma (coef. correlattion 0,615) dan ISPA (coef. correlattion 0,736 ) adalah kuat. Tingkat 
kekuatan hubungan antara kadar ISPU dengan iritasi mata (coef. correlattion 0,523) adalah cukup kuat. Kekuatan hubungan antara kadar ISPU dengan pneumonia (coef. correlattion 0,3611), iritasi kulit (coef. correlattion 0,364) dan diare (coef. correlattion 0,344) adalah lemah. Angka correlation coefficient bernilai positif, sehingga hubungan antara variabel kadar ISPU dan gangguan kesehatan fisik bersifat searah.

\section{SARAN}

Berdasarkan penelitian dapat disarankan beberapa hal, yaitu perlunya studi cohort lanjutan terkait dampak kebakaran hutan dan lahan terhadap resiko gangguan kesehatan fisik.

\section{DAFTAR PUSTAKA}

Anggraini, IM., AH Sutomo \& Sukandarrumidi. (2015). Pengaruh Kabut Asap pada Pneumonia Balita di Kota Pontianak. Berita Kedokteran Masyarakat 32 (4) : $113-118$

Araviiskaia E, E Berardesca, T Bieber, G Gontijo, MS Viera, L Marrot, B Chuberre, \& B Dreno. (2019). The Impact of Airborne Pollution on Skin. Journal of the European Academy of Dermatology and Venereology 33(8):1496-1505

Awaluddin. (2016). Keluhan Kesehatan Masyarakat Akibat Kabut Asap Kebakaran Hutan dan Lahan di Kota Pekanbaru. Journal Endurance 1 (1): $37-46$

Dijkhoff IM, B Drasler, BB Karakocak, A Petri-Fink, G Valacchi, M Eeman \& B
Rothen-Rutishauser. (2020). Impact of Airborne Particulate Matter on Skin: a Systematic Review from Epidemiology to in vitro Studies. Particle and Fiber Toxicology 17 (35): $1-28$

Dinas Kesehatan Provinsi Riau. (2019). Profil Kesehatan Provinsi Riau Tahun 2018. Dinkes Provinsi Riau, Pekanbaru

Faisal, F., F. Yunus \& F. Harahap. (2012). Dampak Asap Kebakaran Hutan pada Pernafasan. Cermin Dunia Kedokteran 39 (1): 31 - 35

Gunawan, A., M Rivai \& E Setiadji. (2012). Pengukuran Kadar Kepekatan Asap pada Lahan Gambut. Prosiding Seminar Nasional Teknologi Informasi dan Komunikasi Terapan, Semarang 2012. Hal. $2-6$

Harahap, N., G. Indriati \& WN Dewi. (2019). Hubungan Pemberian Makanan Pendamping ASI (MPASI) Dini dengan Kejadian Diare Pada Bayi Usia 0-6 Bulan. Jurnal Online Mahasiswa Fakultas Keperawatan 6 (1) : $81-88$

Hermawan, A., M. Hananto \& D. Lasut. (2016). Peningkatan Indeks Standar Pecemaran Udara (ISPU) dan Kejadian Gangguan Saluran Pernafasan di Kota Pekanbaru. Jurnal Ekologi Kesehatan 15 (2): 76 $-86$

Huff RD, C Carlsten \& JA Hirota. (2019). An Update on Immunologic Mechanisms in the Respiratory Mucosa in Response to Air Pollutants. Journal of Allergy and Clinical Immunology 143(6):19892001

Jeffrey A \& A. Theresa. (2014). Respiratory Ephitelial Cells Orchestrate Pulmonary Innate Immunity. National Immunology Journal 16 (10) : 27 - 35

Kementerian Kesehatan RI. (2003). Keputusan Menteri Kesehatan 
Putra Mulia, Nofrizal, Wan Nishfa Dewi, Analisis Dampak Kabut Asap Karhutla terhadap Gangguan Kesehatan Fisik

Nomor 289/MENKES/SK/III/ Tahun 2003 tentang Dampak Cemaran Udara. Kemenkes RI, Jakarta .(2016). Kemenkes Tanggapi Hasil Studi Kematian akibat Karhutla. http://kemkes.go.id diakses pada tanggal 20 Juli 2020

$$
\text { (2019). Riset }
$$

Kesehatan Dasar Tahun 2018.

Kemenkes RI, Jakarta

Kementerian Lingkungan Hidup dan Kehutanan RI. (1997). Keputusan Menteri Lingkungan Hidup Nomor KEP-45/MENLH/10/1997 tentang Indeks Standar Pencemar Udara. KemenLH RI, Jakarta

Koplitz, SN. (2016). Public Health Impacts of the Severe Haze in Equatorial Asia in September - October 2015: Demonstration of a New Framework for Informing Fire Management Strategies to Reduce Downwind Smoke Exposure. Environmental Research Letters 11 (2016) 094023

Kunii, O., S Kanagawa, I Yajima, Y Hisamatsu, S Yamamura, T Amagai \& S Ismail. (2002). The 1997 Haze Disaster in Indonesia: its Air Quality and Health Effects. Environmental Health: An International Journal 57 (1)

Maharani, C., AA Asrial, Purba BA dan Miftahurrahmah. (2020). Edukasi Dampak Kesehatan dan Upaya Perlindungan Diri Dari Bencana Kabut Asap. MEDIC 3 (1): $22-26$

Prayitno SAE. (2019). Hubungan Perilaku Hidup Bersih Dan Sehat Rumah Tangga Terhadap Kejadian Infeksi Saluran Pernafasan Akut Dan Diare Pada Balita. Skripsi, Universitas Airlangga. Surabaya (Tidak Diterbitkan)

Pudiastuti, RD. (2011). Waspadai Penyakit pada Anak. Indeks, Jakarta

Said M. (2010). Pengendalian Pneumonia Anak Balita dalam Rangka Pencapaian MDG4. Buletin Jendela Epidemiologi $3: 16-21$
Smeltzer, SC. (2016). Keperawatan medikal bedah Brunner dan Suddarth Edisi 12. EGC, Jakarta

Sugiarto, Subakir dan Prayitno. (2019). Faktor Risiko Kejadian Diare Pada Balita. Scientific Periodical of Public Health and Coastal Health 1 (1) : 21 $-31$

Susanto, AD, N Arifin, S Erlang, J Zaini, F Yunus, F Fitriani, F Isbaniah, M Ikhsan, Prasenohadi \& A Ginanjar. (2019). Pencegahan dan Penanganan Dampak Akibat Asap Kebakaran Hutan. UI Press, Jakarta

Vinay K, S. Ramzi \& R. Stanley. (2007). Inflamasi akut dan inflamasi kronik. Dalam: Huriwati H, Nurwany D, Nanda W, editors. Buku Ajar Patologi Robbins. Edisi ke-7. EGC, Jakarta.

Yudhawati, R \& DPA Krisdanti. (2017). Imunopatogenesis Asma. Jurnal Repirasi 3 (1): 26 - 33

WHO. (1999). Health Guidelines for Vegetations Fire Events. WHOUNEP-WMO Guidelines Workshop. Lima, Peru

Wulan, AJ \& S. Subagio. (2016.) Efek Asap Kebakaran Hutan terhadap Gambaran Histologis Saluran Pernafasan. Majority 5 (3): 162 167 